\title{
Literackie zwierzę poza stereotypami? Analiza wizerunku lisa w powieści Pax Sary Pennypacker z perspektywy animal studies oraz posthumanizmu
}

\section{Abstrakt:}

Artykuł dotyczy wizerunku lisa w skierowanej do młodych czytelników powieści Pax (2016) autorstwa Sary Pennypacker. W pierwszej części przywołano i objaśniono wypracowane na gruncie animal studies oraz posthumanizmu koncepcje istotne w kontekście badania zwierzęcych reprezentacji. Autorka omawia również obecność lisa w kulturze i literaturze i przygląda się sylwetkom lisich bohaterów w twórczości pisarskiej dla dzieci. Następnie poddaje szczegółowej analizie postaci lisów w utworze Pennypacker. Autorka artykułu bada zwierzęta pod kątem autentyczności ich przedstawienia oraz docieka, jakie zabiegi literackie wpływają na kształtowanie się wizerunku lisa w tej powieści.

\section{Słowa kluczowe:}

animal studies, Inny, lis, literatura dziecięca, Pax, posthumanizm, Sara Pennypacker, zwierzę, zwierzęca perspektywa

\section{A Literary Animal Beyond Stereotypes? Analysis of the Image of The Fox in Sara Pennypacker's Novel Pax from the Perspective of Animal Studies and Posthumanism}

\section{Abstract:}

This text concerns the image of the fox in Sara Pennypacker's novel Pax (2016) directed at young people. In the first part, the author invokes and clarifies concepts from the field of animal studies and posthumanism that are relevant to the research of the animal representation in literature. The author also discusses the general presence of the fox in culture and literature, she especially scrutinises the fox characters in children's literature. Then, she subjects the fox characters in Pennypacker's

* Karolina Sinkowska - lic., absolwentka Wydziału Polonistyki Uniwersytetu Warszawskiego. Interesuje się m.in. twórczością skierowaną do młodego odbiorcy oraz wizerunkami zwierząt w literaturze i kulturze. Kontakt: k.sinkowska@student.uw.edu.pl. 
novel Pax to a detailed analysis. The author studies the authenticity of the descriptions and investigates what literary tropes are shaping the image of the fox in the novel.

Key words:

animal studies, the Other, fox, children's literature, posthumanism, Pax, Sara Pennypacker, animal, animal's perspective

\section{Wprowadzenie}

B adanie zwierząt innych niż człowiek wciąż jest dla naukowców dużym wyzwaniem. Jako ogół gatunków żyjemy na jednej planecie od tysięcy lat, jednak do tej pory nie wykształciliśmy wspólnego dla nas wszystkich narzędzia komunikacji ${ }^{1}$. To właśnie nieznajomość ludzkiego języka, w oczach homo sapiens, w podstawowy sposób dyskwalifikuje nie-ludzkie zwierzęta $\mathrm{w}$ budowaniu potencjalnej relacji partnerskiej z człowiekiem. Mimo to współcześnie obserwuje się coraz większe zainteresowanie odmiennymi gatunkami - zwierzęta są popularnym obiektem badań człowieka, przedmiotem dyskusji etycznej oraz źródłem inspiracji w sztuce ${ }^{2}$. Literatura piękna, będąca dziedziną sztuki, która zatrzymała w czasie ludzkie wyobrażenia o świecie oraz dała człowiekowi możliwość wglądu do myśli minionych epok, jest szczególnie cennym źródłem informacji o tym, jak m.in. zmieniał się stosunek ludzi do pozostałych zwierząt i w jaki sposób ewoluowały wizerunki nie-ludzi w tekstach kultury. I tak oto lis, najważniejszy bohater niniejszego artykułu, przedstawiany był w wielowiekowej tradycji jako alegoria sprytu. Tymczasem współcześnie - wraz z rozwojem wiedzy o tym gatunku³ - pojawiają się książki, które opisują to zwierzę jako istotę wielowymiarową; przypisują jej np. poznane cechy osobnicze.

Co ciekawe, ambicją współczesnych pisarzy nie są już tylko próby opisu zwierząt w zgodzie z faktami biologicznymi, lecz także charakterystyka

1 Oczywiście nie mam tu na myśli biologicznie uwarunkowanych możliwości komunikacji niewerbalnej - wszyscy komunikujemy się poprzez nasze ciała, stany emocjonalne, jednakże tylko język umożliwia swoim użytkownikom oddanie informacji złożonych i abstrakcyjnych.

2 W sztuce zwierzęta pojawiły się zdecydowanie najwcześniej; znamienny jest fakt, że sztuka naskalna - pierwsze wyrazy artystyczne człowieka - przedstawia zwierzęta: m.in. jelenie, byki, żubry, konie.

3 W przypadku Paxa - głównie pod wpływem znajomości zachowania lisów w ich habitacie (Pennypacker, 2016, s. 291). 
świata widzianego oczami tychże zwierząt. Z tego rodzaju wyzwaniem mierzy się Sara Pennypacker (2016) w powieści Pax, której tytułowym bohaterem jest lis $\mathrm{i}$ to $\mathrm{m}$.in. $\mathrm{z}$ jego punktu widzenia prowadzona jest narracja $\mathrm{w}$ utworze. Pozycja ta zasługuje w moim odczuciu na szczególną uwagę i docenienie; pogłębiona wiedza autorki na temat biologii lisów ${ }^{4}$ zaowocowała literackimi konstruktami tych zwierząt, które są naukowo rzetelne, a przez to możliwie rzeczywiste. W niniejszym artykule przeanalizuję, w jaki sposób Pennypacker buduje postaci zwierzęce ${ }^{5}$ oraz lisią perspektywę w powieści. Przyjrzę się zabiegom narracyjnym, językowym oraz fabularnym, które stwarzają lisa w utworze i pozwalają autorce osiągnąć możliwie najgłębszy efekt prawdopodobieństwa postaci. Interesować mnie będą również ograniczenia $\mathrm{w}$ tworzeniu opisu zoocentrycznego oraz zastosowane przez Pennypacker rozwiązania formalne. Do analizy posłużę się narzędziami wypracowanymi przez reprezentantów posthumanizmu oraz animal studies; konieczne jest zatem krótkie zaprezentowanie teorii, związanej z nowymi kierunkami badań nad zwierzętami. W dalszej części tekstu zapoznam czytelników z tradycyjnymi (i nieco mniej tradycyjnymi) przedstawieniami literackich lisów w wybranych utworach ${ }^{6}$, by wreszcie we właściwej analizie przemyśleć nowy (wobec tradycji) wizerunek lisa w powieści Pax.

\section{Posthumanizm, animal studies i zwierzęcy Inni}

W ujęciu Anny Barcz (2013), posthumanizm zapoczątkowuje kulturoznawczą, a w tym literaturoznawczą refleksję nad statusem człowieka oraz innych zwierząt. Autorzy posthumanistyczni odchodzą bowiem od uznawania świata, w którym homo sapiens góruje nad resztą stworzenia, i coraz częściej podkreślają istnienie nie-ludzkiego „Innego” (Gajewska, 2015; Zawojski, 2017). Obecna popularność tej kategorii świadczy o głębokiej potrzebie uwzględniania zarówno

4 Autorka przygotowywała się do napisania powieści pod okiem wieloletniego obserwatora i badacza tych zwierząt, Matthew Waltera (Pennypacker, 2016, s. 291).

5 Ze szczególnym uwzględnieniem głównego bohatera.

6 Część artykułu, o której mowa, ma za nadrzędne zadanie wprowadzić czytelnika w kontekst tradycyjnych przedstawień lisa w kulturze; nie jest zaś wyczerpującym źródłem wiedzy w tym obszarze. Nie zajmuję się syntetycznym badaniem przeobrażeń wizerunku lisa w literaturze, gdyż zagadnienie to wymaga osobnego, obszerniejszego opracowania. Wybór utworów z lisim protagonistą/antagonistą był zatem subiektywny; powołuję się na teksty, które w moim odczuciu eksponują istotne elementy tradycyjnego obrazowania literackich lisów, by w ten sposób naszkicować odbiorcy swego rodzaju tło dla analizy Paxa. 
ludzkiej, jak i nie-ludzkiej odmienności w refleksji naukowej; o potrzebie gromadzenia i upowszechniania wiedzy na temat Innych: etnicznie, kulturowo, ale także gatunkowo ${ }^{7}$.

Stwierdzenie, że nie-ludzkie zwierzę jest Innym, choćby przez sam fakt nie-bycia człowiekiem, wydaje się banalne. Trzeba jednak zauważyć, że pojęcie zwierzęcia jest ogólne i mieści w sobie niezliczoną ilość gatunków ${ }^{8}$. Kategoria Innego rozszerza się zatem na każdy z nich z osobna, a przy założeniu, że wiedza człowieka na temat innych zwierząt będzie się pogłębiać, kategoria ta obejmie również poszczególnych przedstawicieli rozpoznanych przez badaczy gatunków. Nie wystarczy też konstatacja, że człowiek i nie-ludzkie zwierzę różnią się od siebie, a tym bardziej - wyłącznie pod względem fizyczności; potrzeba szczegółowych informacji dotyczących rozmaitych płaszczyzn, na których ta odmienność się ujawnia. Nie-ludzkie zwierzęta w zupełnie inny sposób postrzegają i rozumieją świat. Cechują się też odmiennymi sposobami myślenia i komunikowania treści między osobnikami tego samego gatunku. W nowej humanistyce omawiane problemy podejmowane są przede wszystkim $\mathrm{w}$ ramach interdyscyplinarnych studiów nad zwierzętami - ukonstytuowanych na nieantropocentrycznych założeniach ${ }^{9}$. Anna Mik, Patrycja Pokora i Maciej Skowera (2016) zwracają uwagę, że na gruncie literaturoznawczym badania te często przybierają formę analiz „tekstowych reprezentacji nie-ludzkich zwierząt z wyczytywaniem $\mathrm{z}$ utworów »Zwierzęcości« jako stworzonego przez człowieka konstruktu” oraz „etycznego, empatycznego i afektywnego namysłu nad literackim zwierzęciem” (s. 12).

Szczególnie ważną pozycją polskojęzyczną, zawierającą przekłady obcojęzycznych opracowań z zakresu animal studies oraz próby krytyczne rodzimych badaczy, jest antologia Zwierzęta, gender i kultura pod redakcją Barcz oraz Magdaleny Dąbrowskiej (2014). W tekście Kari Weil (2010/2014), którego tłumaczenie otwiera pierwszą część tomu, padają kluczowe pytania dla wszelkich obszarów badań nad zwierzętami: „W jaki sposób możemy wprowadzić zwierzęcą

7 Pojęcie „Inny” odnoszone było początkowo przede wszystkim do człowieka; z tego względu powstał szereg tekstów opisujących i definiujących odmienność wyłącznie istot ludzkich. Pośród prac, które poruszają to zagadnienie na rodzimym gruncie, można wymienić książkę Mieczysława Dąbrowskiego (2001), artykuł Honoraty Gruchlik (2007), a także zbiór wykładów Ryszarda Kapuścińskiego (2006).

8 O koncepcie zwierzęcia, „przechowującego” w sobie wszystkie stworzenia poza człowiekiem pisał Jacques Derrida (2006/2008).

9 Animal studies wpisują się zatem w szerszy nurt myślenia posthumanistycznego. Dowodem na to niech będą prace badaczek zainteresowanych krytyką posthumanistyczną, które piszą także o kwestii zwierzęcej (Bakke, 2011; Barcz, 2013; Braidotti, 2013). 
odmienność w ramy teorii?”, „[...] jak rozumieć innych i oddać głos im lub ich doświadczeniom, które są nieprzeniknione dla naszych sposobów rozumienia; w jaki sposób pielęgnować odmienność, nie zawłaszczając czy nie zniekształcając jej?”, wreszcie: „[...] w jaki sposób słyszeć i uznawać coś, co może nie być możliwe do wypowiedzenia?” (s. 17-18). Choć współczesna nauka nie znalazła jeszcze odpowiedzi na postawione przez badaczkę pytania ${ }^{10}$, świadomość problemów, które towarzyszą posthumanistycznym studiom nad zwierzętami, jest niezbędna zarówno naukowcom, jak i odbiorcom ich badań. W wymiarze ogólnym świadomość ta przekłada się bowiem na pogłębione rozumienie podobieństw i różnic między ludźmi i innymi zwierzętami; w wymiarze literaturoznawczym zaś na uważniejszą analizę konstruktów zwierzęcych w tekstach literackich.

\section{Lis w tradycji europejskiej i polskiej oraz w literaturze dziecięcej}

Lis zamieszkuje literackie światy już od starożytności. Jego stała obecność na gruncie literatury niezależnie od długości i szerokości geograficznej wynika według Anny Korpalskiej (2015) z dużego rozpowszechnienia tego gatunku na Ziemi: „Lis cechuje się wyjątkowymi zdolnościami adaptacyjnymi. Występuje w różnych środowiskach, od terenów półpustynnych po lasy. [Z tego względu] został połączony z wieloma tradycjami” (s. 13).

Korpalska (2015) poświęca postaci lisa monografię Lis $w$ kulturze Japonii, skoncentrowaną przede wszystkim na omówieniu figury zwierzęcia w tradycyjnym folklorze Kraju Kwitnącej Wiśni. W książce zamieszcza także krótki, lecz cenny z punktu widzenia moich badań rozdział o występowaniu lisa w innych tradycjach kulturowych ${ }^{11}$. Badaczka wskazuje przykład Japonii, w której postać lisa wiąże się m.in. ze zdolnościami magicznymi, i stwierdza, że

10 Znaczące braki w wiedzy o zwierzętach zaobserwować można w różnych dziedzinach badań. Przykładem pracy na nowo wprowadzającej nie-ludzi - w tym wypadku na arenę badań historycznych, które skupiały się do niedawna wyłącznie na człowieku - jest przełomowa dla animal studies książka Érica Barataya (2014).

11 Korpalska poświęciła zaskakująco mało uwagi kwestii występowania lisa w kulturze Chin, choć o zwierzęciu tym powstało wiele tekstów anglojęzycznych (np. Kang, 1999, 2006; Wang, 2009). Mimo że opracowania te dotyczą w dużej mierze wizerunku lisa w kulturze i literaturze (a zatem są związane $z$ omawianym przeze mnie zagadnieniem), odmienne reprezentacje tych zwierząt, wynikające $z$ różnic kulturowych wobec wzorca europejskiego (żywotnego wciąż w krajach anglojęzycznych, z których wywodzi się Pax), są powodem, dla którego nie mogę uwzględnić wyników tych badań w niniejszym artykule, zważywszy na jego ograniczone rozmiary. 
w tradycji europejskiej występuje on w roli „naczelnego chytrusa, figlarza i mąciwody” (s. 14). Dodaje również, że: „w zależności od regionu przypisywane mu były różnorakie cechy, rozmaicie też interpretowano jego zachowanie" (s. 13) - mimo to spryt i ponadprzeciętna inteligencja stanowiły atrybuty, z którymi zwierzęta te kojarzono niezależnie od kultury i kraju.

Jedną z pierwszych reprezentacji lisa w literaturze jest ta ze starożytnych bajek zwierzęcych, których autorstwo przypisuje się Ezopowi (Korpalska, 2015, s. 14). Lis pojawia się w nich „aż czterdzieści razy, ustępując pod względem liczby [wystąpień] jedynie lwu" (Koizuka, 1982; za: Korpalska, 2015, s. 14). W utworach tych zwierzę cechuje się szczególnym intelektem, bystrym umysłem, ciętym językiem i sprytem; nie postępuje ono jednak obłudnie. Lisa nie utożsamia się jeszcze z „psotnikiem ani intrygantem”, jego postać „nie wykazuje się też szczególną złośliwością" (s. 14). Zasadnicza zmiana w tym względzie dokonuje się dopiero w wiekach średnich:

Zdrajcą, zbrodniarzem i krzywoprzysięzcą, którego jednakowoż można podziwiać za niebywałą inteligencję, jest lis Renart (ang. Reynard, niem. Reineke) główny bohater opowieści, które w swych kolejnych odsłonach cieszyły się niezwykłą popularnością w średniowiecznej Europie Zachodniej (s. 15).

Począwszy od XIII wieku, coraz to nowsze warianty eposu o Renarcie rozpowszechniano $\mathrm{z}$ powodzeniem $\mathrm{w}$ języku angielskim, francuskim, niemieckim i holenderskim. „Opierały się one na wspólnym schemacie, zbierającym luźne wątki z podań ludowych o kolejnych szelmostwach lisa" (s. 15). Zainspirowany nimi Johann Wolfgang von Goethe (1794/1973) wprowadził Renarta w poczet arcydzieł literatury, czyniąc go głównym bohaterem epopei Reineke Fuchs [Lis Renart] (w tłumaczeniu Leopolda Staffa - Lis Przechera; Goethe, 1794/1986).

Warto w tym miejscu zaznaczyć, że wizerunek lisa na rodzimym gruncie nie był jedynie odtworzeniem zagranicznych wzorców, ani też nie był budowany wyłącznie na tłumaczeniach obcojęzycznych utworów. Zwierzę to, przedstawiane jako uosobienie sprytu i przebiegłości, pojawiało się bowiem także w bajkach ludowych polskiego pochodzenia ${ }^{12}$. Iwona Rzepnikowska (20162018) w szczegółowej charakterystyce tych utworów pisze:

W fabułach zwierzęcych lis występuje zazwyczaj w roli chytrego zdobywcy, doradcy, sędziego, przewodnika, negocjatora, ale zgodnie $\mathrm{z}$ obowiązującą $\mathrm{w}$ tego

12 Więcej informacji o poszczególnych bajkach dostarcza Słownik polskiej bajki ludowej (Wróblewska, 2016-2018). 
typu opowieściach zasadą zbiegu przeciwieństw może okazać się przegranym, gdy spotka sprytniejszego od siebie.

Badaczka ta zauważa również, że w obrębie polskiej bajki zwierzęcej jedną z częściej obieranych przez lisiego bohatera strategii jest wyolbrzymianie zalet rywala, które umożliwia mu osiąganie zamierzonych korzyści. Przykładem czytelnie ilustrującym taki schemat działania postaci jest bajka Kruk i Lis Ignacego Krasickiego $(1779 / 2019)^{13}$ :

Bywa często zwiedzionym,

Kto lubi być chwalonym.

Kruk miał w pysku ser ogromny;

Lis, niby skromny,

Przyszedł do niego i rzekł: „Miły bracie,

Nie mogę się nacieszyć, kiedy patrzę na cię!

Cóż to za oczy!

Ich blask aż mroczy!

Czyż można dostać

Takową postać?

A pióra jakie!

Szklniące, jednakie.

A jeśli nie jestem w błędzie,

Pewnie i głos śliczny będzie."

Więc kruk w kantaty; skoro pysk rozdziawił,

Ser wypadł, lis go porwał i kruka zostawił.

Fakt, że lis przemawia w tym utworze ludzkim głosem, czyni go bardziej człowiekiem w lisim przebraniu aniżeli rzeczywistym zwierzęciem. Należy jednak pamiętać, że:

Dawniej zwierzęta literackie najczęściej odsyłały - na zasadzie symbolu bądź alegorii - do repertuaru skonwencjonalizowanych kulturowych znaczeń. Choć ta tradycja nie zanikła, to współcześnie przedmiotem referencji coraz częściej stają się zwierzęta rzeczywiste i nękające je problemy - zwłaszcza kwestia przemocy, której te istoty doświadczają ze strony człowieka (Mik, Pokora, Skowera, 2016, s. 10).

Z tego też względu, to właśnie we współczesnej literaturze, a szczególnie w tej kierowanej do młodego czytelnika, warto i należy dopatrywać się zwierzęcych

13 Ściślej mówiąc, Kruk i lis jest utworem Jeana de La Fontaine’a na podstawie bajki Ezopa; Krasicki jest zaś oryginalnym tłumaczem tekstu. W wielu polskich wydaniach Krasicki widnieje jednak jako autor bajki, m.in. w tym, do którego odwołuję się w niniejszym artykule. 
reprezentacji, w swym założeniu mających odnosić do autentycznych nie-ludzkich istot, nie zaś do zestawu cech czy zachowań, które zostały im przypisane na mocy konwencji. Powinno się jednak pamiętać, że omawianie wizerunku zwierzęcia w swoistym repertuarze utworów dla dziecięcego odbiorcy wymaga zbadania także szaty graficznej, która stanowi - zwłaszcza w ich przypadku integralną $\mathrm{i}$ istotną $\mathrm{w}$ interpretacji część dzieła.

Lis pojawia się w tekstach dla dzieci i młodzieży nader często ${ }^{14}$; w utworach XIX- i XX-wiecznych nierzadko wciąż jako postać negatywna, której bohaterowie literackich światów winni się wystrzegać. W tym kontekście warto wspomnieć choćby Pinokia Carla Collodiego (1883). Lisica ${ }^{15}$ wraz z kotem udają w utworze kaleki, bałamucą pajacyka i wykorzystują jego dziecięcą naiwność. Podobny wizerunek zwierzęcia, choć jeszcze wyraźniej zantropomorfizowany, ukazuje Disneyowska adaptacja (Sharpsteen, Luske, 1940) tej historii - lis w filmie chodzi na dwóch łapach, utrzymuje pozycję wyprostowaną, nosi ubrania, a ponadto przemawia, porusza się i zachowuje jak człowiek ${ }^{16}$.

Odmiennego przykładu dostarcza postać tytułowego Fantastycznego Pana Lisa z powieści Roalda Dahla (1970/2017). Kreację bohatera zwierzęcego tworzą tu po części ilustracje Quentina Blake’a - rysownika, z którym Dahl przez wiele lat współpracował. Co prawda w warstwie graficznej lis nosi ubrania, mieszka $\mathrm{z}$ żoną i czworgiem dzieci w miejscu przypominającym przyjemnie urządzone mieszkanie. Co jednak najistotniejsze, w warstwie tekstowej Dahlowski lis jest postacią ocenianą pozytywnie, a spryt i inteligencja są jego atutami:

Ilekroć podkradał się do farmy, szedł pod wiatr, i jeśli ktokolwiek czaił się na niego gdzieś w dalekich ciemnościach, zapach czyhającego docierał wraz z podmuchami powietrza wprost do lisiego nosa. Jeśli na przykład pan Gnojek krył się za swoim kurnikiem numer jeden, Lis wyczuwał jego obecność z odległości pięćdziesięciu jardów, szybko zmieniał marszrutę i kierował się na kurnik numer dwa, na drugim końcu farmy (s. 11).

14 Omawiana wcześniej bajka zwierzęca - współcześnie czytana głównie dzieciom - pierwotnie kierowana była do dorosłych.

15 We włoskim oryginale występuje nie lis, lecz lisica (wynika to zapewne z faktu, iż rzeczownik 'lis' jest w języku włoskim rodzaju żeńskiego). Zostało to uwzględnione w nowym przekładzie Jarosława Mikołajewskiego (Collodi, 1883/2011).

16 Co ciekawe, ilustrator pierwszego wydania oryginalnego Pinokia - Enrico Mazzanti przedstawił na rycinach sylwetki przypominające rzeczywiste zwierzęta (Collodi, 1883). Dopiero późniejsze edycje utworu wraz z filmowymi adaptacjami zantropomorfizowały duet lisa i kota także pod względem graficznym, można tu wspomnieć np. ilustracje Roberta Innocentiego (Collodi, 1883/2011) czy Jana Marcina Szancera (Collodi, 1883/1988). 
W opisie pojawiają się też strategie uprawdopodobniające zwierzęcość Pana Lisa - bohater kieruje się zmysłem węchu, instynktem; jest ostrożny wobec człowieka i jego działań.

Wyjątkowy na zarysowanym tle wydaje się wreszcie wizerunek lisa, który czytelnik odnajduje w Małym Księciu Antoine’a de Saint-Exupéry’ego (1943/2018). Zwierzę odgrywa tu szczególną rolę - przekazuje życiowe prawdy, skłania do refleksji na temat odpowiedzialności i istoty przyjaźni. Relacje dzieci i zwierząt jako równych sobie istot żywych są obrazowane przez wzajemnie oswojonych lisa i księcia. I choć lisi bohater w utworze ma świadomość na poły ludzką (mówi: „Ludzie mają zbyt mało czasu, aby cokolwiek poznać. Kupują w sklepach rzeczy gotowe. A ponieważ nie ma magazynów z przyjaciółmi, więc ludzie nie mają przyjaciół”, s. 49), wyraża też to, co jawi się jako doświadczenie zwierzęce: „Z daleka będę rozpoznawał twoje kroki - tak różne od innych. Na dźwięk cudzych kroków chowam się pod ziemię. Twoje kroki wywabią mnie z jamy" (s. 48-49). Saint-Exupéry oferuje zatem odmienny i nowatorski wobec tradycji literackiej obraz lisa jako postaci szczególnie przyjaznej i łączonej z życiową mądrością. Postać ta nie odsyła jednak w swej tekstowej reprezentacji do autentycznego zwierzęcia, które patrzy na świat i rozumie go inaczej niż człowiek.

$\mathrm{W}$ najnowszych utworach, za sprawą posthumanistycznego zwrotu ku zwierzętom, coraz większe grono twórców dąży do przedstawienia postaci nie-ludzkich w sposób możliwie jak najrzetelniejszy (zgodny $\mathrm{z}$ wiedzą naukową o danym gatunku). Przykładem takiego tekstu jest Pax Sary Pennypacker, przejdę zatem teraz do jego właściwej analizy.

\section{Lis(y) w powieści Pennypacker}

Tytułowy bohater powieści był szczenięciem, gdy jego lisią mamę potrącił samochód, a rodzeństwo z miotu umarło z głodu i wychłodzenia. Odnalazł go Peter, chłopiec, który w naturalnym odruchu (po niedawnej stracie własnej mamy) zabrał zwierzę do domu, otoczył opieką i oswoił z bliskością człowieka. Powieść otwiera scena rozgrywająca się pięć lat później - Peter, jego ojciec oraz lis Pax zmierzają w stronę lasu, gdzie zwierzę ma zostać porzucone. Wieści o nadchodzącej wojnie sprawiły, że miasto, w którym mieszkali bohaterowie, opustoszało. Ojciec zgłasza się jako ochotnik do wojska i organizuje synowi przeprowadzkę do oddalonego o pięćset kilometrów dziadka; autorytarnie oznajmia także chłopcu, że jego lis musi zostać wypuszczony na wolność. Dorosły mężczyzna nie przyjmuje sprzeciwu syna, nie zważa 
też na relację zbudowaną między dzieckiem a zwierzęciem. Zaprzyjaźnieni bohaterowie jako istoty podporządkowane ludziom dorosłym ${ }^{17}$ nie mają głosu, by zawalczyć o dalszy wspólny los. Kiedy wszyscy trzej kierują się samochodem w stronę lasu, Peter jest zrozpaczony i zalękniony. Nie bez przyczyny jednak autorka decyduje się na przedstawienie przebiegu sceny właśnie z perspektywy zwierzęcia. Czytelnik, uczestnicząc w wydarzeniach opisanych z punktu widzenia lisa, nie wie - podobnie jak zwierzę - co za chwilę nastąpi:

Lis wcześniej niż chłopiec wyczuł, że samochód zwalnia, bo wszystko wyczuwał pierwszy. To wzbierało w opuszkach, w kręgosłupie, we wrażliwych włoskach na przednich łapach. Po wibracjach poznał, że droga stała się bardziej wyboista. Poderwał się z kolan chłopca i skierował nozdrza ku smugom woni wpływającym przez okno. Wiedział, że wjeżdżają do lasu. Intensywny zapach sosen - drewna, kory, szyszek i igieł - niczym ostrze noża wrzynał się w powietrze, ale gdzieś pod nim ukrywały się łagodniejsze wonie koniczyny, dzikiego czosnku i paproci oraz setek innych rzeczy, z którymi lis nigdy wcześniej się nie zetknął, a pachniały zielenią i rozbuchaniem (Pennypacker, 2016, s. 9-10).

Przytoczona scena dostarcza czytelnikowi pierwszej istotnej informacji o kreacji lisiego bohatera w utworze - poznawanie świata przedstawionego przez lisa opiera się na wrażeniach zmysłowych; Pax nie tyle przygląda się nowemu otoczeniu, ile wyczuwa je wszystkimi elementami swojego ciała, co przywodzi na myśl zjawisko synestezji. W opisie szczególnie zwraca uwagę dokładność, z jaką Pennypacker stara się przedstawić lisi węch. Kiedy do Paxa docierają pierwsze zapachy leśnej roślinności, lisi zmysł, znacznie bardziej czuły od węchu człowieka, pozwala mu na postrzeganie każdego z nich $\mathrm{z}$ osobna. Beata Mytych-Forajter (2019, s. 227) zwraca natomiast uwagę na fragmenty, w których Pax nasłuchuje ziemi, by dowiadywać się od niej o zdarzeniach, których jeszcze nie widać na horyzoncie. Należałoby zatem stwierdzić, że perspektywa zwierzęcia w powieści jest nieokulocentryczna.

Przywoływana już Barcz (2013) pisze o zjawisku tzw. „fokalizacji zwierzęcej”, które polega na „wytwarzaniu doświadczenia zwierzęcego w tekście na poziomie wszystkich zmysłów i konstrukcji bohatera”. W literackim opisie ponadto „kwestia punktu widzenia przeradza się w konstrukcję narracyjną, a pewne strategie uprawdopodobniające nie-ludzką ekspresję - w postać tekstową" (s. 112). Rozpoznania badaczki bardzo celnie opisują rozwiązanie

17 Więcej o podobnym położeniu dziecięcych i zwierzęcych bohaterów pisał Skowera (2016). 
zastosowane przez Pennypacker w omawianej powieści. Cytowany wcześniej fragment ujawnia, że konstrukcja lisiego bohatera w utworze wiąże się ściśle z przedstawianiem jego zmysłowego sposobu poznawania świata. Z kolei inicjujący powieść moment rozdzielenia chłopca i lisa przerywa linearną ciągłość narracji i przekłada się na zakomponowanie rozdziałów; są one bowiem od tej pory ułożone naprzemiennie, ukazując raz perspektywę chłopca, raz lisa (tok narracji jest jednak trzecioosobowy). Warto zwrócić uwagę, że motto utworu dodatkowo podkreśla wagę zastosowanego zabiegu formalnego: „To, że coś nie dzieje się tutaj, nie znaczy, że nie dzieje się wcale" [wyróżnienie oryginalne] (Pennypacker, 2016, s. 8). W odczytaniu Mytych-Forajter (2019, s. 227) układ rozdziałów oddaje jedność chłopca i lisa; $\mathrm{z}$ całą pewnością jednak dowartościowuje bohatera zwierzęcego i konstytuuje jego obecność w utworze jako pełnoprawnej jednostki.

Historia lisa w utworze utkana jest z momentów narracyjnych, odbywających się tu i teraz, w leśnej przestrzeni, ale też ze wspomnień, które przytaczane są przez narratora płynnie, w toku opowieści - najczęściej w formie skojarzeń. Choć nie wiadomo, czy lisy przywołują wspomnienia tak, jak to robią ludzie (ani też czy w ogóle mają wspomnienia podobne ludzkim), rozwiązanie zastosowane przez autorkę $\mathrm{w}$ powieści nie wywołuje kontrowersji - nie rozstrzyga, w jakiej postaci istnieją (bądź nie) lisie wspomnienia:

[...] pośród setek woni unoszących się z poranną bryzą [Pax] poczuł coś, co przypominało mu chłopca: żołędzie. Peter często nabierał ich całe garście i obsypywał nimi grzbiet Paxa, a potem zaśmiewał się w głos, gdy lis zrzucał je z siebie i rozgryzał, by dostać się do miąższu. W tym momencie znajomy zapach wydał mu się obiecujący i Pax ruszył w jego stronę (Pennypacker, 2016, s. 32).

W chwili, gdy lis wyczuwa żołędzie, narrator korzysta ze swojego przywileju i dopowiada czytelnikowi historię z przeszłości bohaterów. Ta z kolei, zapisana w umyśle lisa na zasadzie pozytywnych skojarzeń (przykładowo poczucia bezpieczeństwa), sprawia, że Pax łączy owoce z postacią Petera i podąża ich śladem. Podobnym scenom w powieści towarzyszą pojedyncze, nieliczne czarno-białe ilustracje autorstwa Jona Klassena (np. rysunek 1 na następnej stronie artykułu). Warto wspomnieć, że postaci lisów są na nich przedstawiane w sposób niezantropomorfizowany; fizycznie przypominają one rzeczywiste zwierzęta szkicowane na potrzeby książki.

Innym zabiegiem służącym wytwarzaniu zwierzęcego doświadczenia w utworze jest zwrócenie uwagi odbiorców na lisie instynkty. Pax został przedstawiony jako istota rozumiejąca rzeczywistość z nie-ludzkiej perspektywy, 

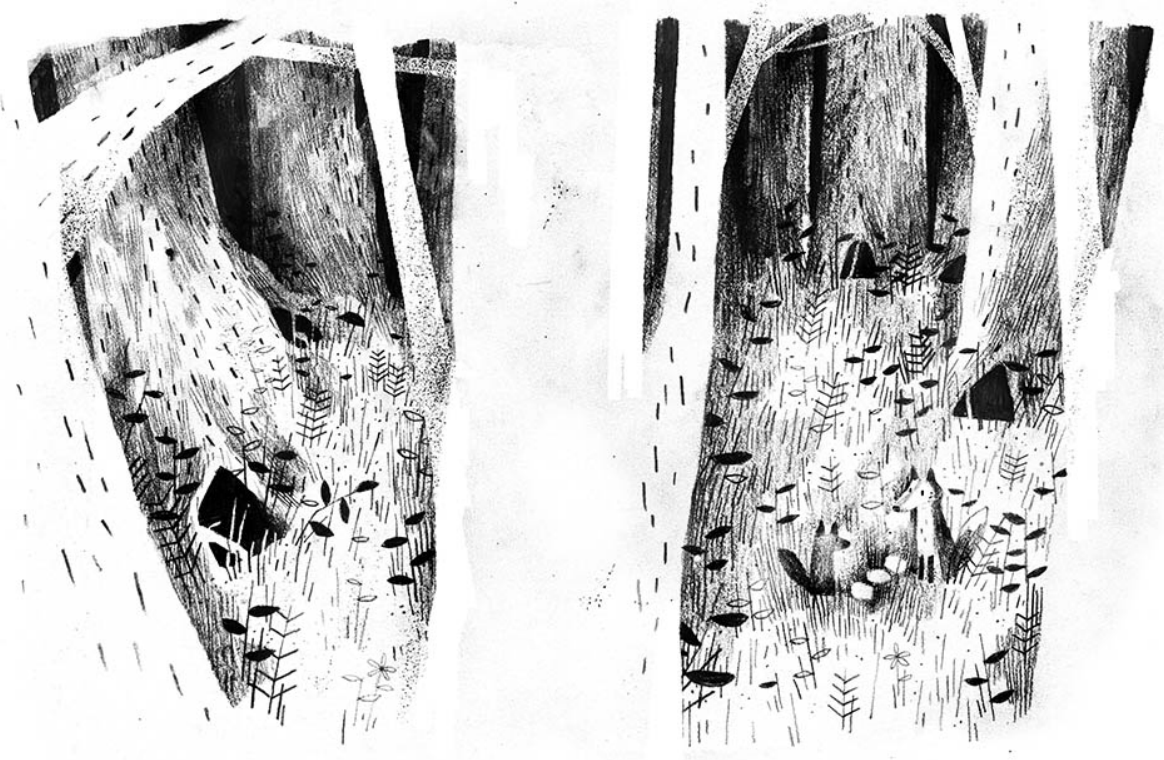

RYSUNEK 1. Jon Klassen, ilustracja do książki Pax.

często w zgodzie z behawiorem swojego gatunku. Czytelnie ilustruje to scena, gdy Pax po raz pierwszy dostrzega mieszkającą w naturze lisicę:

Nigdy wcześniej nie widział innego lisa, a mimo to był pewien: młodszy, mniejszy i rodzaju żeńskiego, ale to lis. Instynkt mówił mu też, że jej sztywno postawione uszy i ogon oznaczają, iż oczekuje od niego uległości (Pennypacker, 2016, s. 42).

Podobnie jest w drugim fragmencie, gdy lis ten - jeszcze jako szczenię - obserwuje starszą kobietę, która pojawiła się w domu Petera: „[...] od tej drobnej kobiety nie wyczuwał nic poza dobrocią i troską" (s. 71). Co ciekawe, w utworze odnaleźć można też sceny, w których Pax przeciwstawia się sile swojego instynktu. Przykładem tego jest fragment, gdy lis - pewien, że jego chłopiec po niego wróci - postanawia czuwać blisko drogi, przy której został porzucony. Ignoruje przy tym wszelkie pokusy, łącznie $\mathrm{z}$,silnym pragnieniem wyruszenia na południe, dokąd pcha go instynkt, nakazujący wracać do domu” (s. 34). Na tym etapie powieści Pax jest jednak bliższy porzuconemu zwierzęciu domowemu $^{18}$, przez co ekspozycja jego lojalności wobec Petera wydaje się zabiegiem celowym i uzasadnionym.

18 Mytych-Forajter (2019) zauważa, że „w powieści Pennypacker lis pełni funkcję psa, o którym marzył chłopiec" (s. 226). 
Wytwarzanie doświadczenia zwierzęcego w Paxie odbywa się także poprzez przenoszenie na grunt powieściowy zaobserwowanych przez przyrodników zachowań lisów ${ }^{19}$. Zabieg ten można dostrzec choćby w scenie, gdy samiec alfa, Szary, mający za zadanie bronić terytorium, na którym pojawił się Pax, prezentuje oswojonemu lisowi swój zapach. Następnie przyjmuje odpowiednią pozycję, stanowiącą informację o tym, jaki jest stosunek alfy wobec głównego bohatera. Narrator podkreśla, że Szary „nie zajął miejsca powyżej”, co oznacza, że w tym momencie narracyjnym „nie stanowi [dla Paxa] zagrożenia" (Pennypacker, 2016, s. 67). Ten opis oraz inne, analogiczne fragmenty utworu stanowią ważny budulec wizerunku lisa jako autentycznie zwierzęcej postaci - skonstruowanej zgodnie z aktualnym stanem wiedzy o zachowaniach gatunku.

Rozpoznania badaczy oraz zainspirowane nimi sceny w powieści Pennypacker wskazują, że lisy reagują w różny sposób, by oznajmić konkretne zamiary wobec drugiego zwierzęcia, np. chcąc okazać mu dominację lub uległość. Mowa ciała stanowi w przypadku lisiego bohatera ważną metodę komunikacyjną, która służy mu nie tylko do kontaktów z osobnikami własnego gatun$\mathrm{ku}$, lecz także do porozumiewania się z człowiekiem. Pax nie kontaktuje się ze swym chłopcem werbalnie, ale do wyrażania potrzeb i pragnień wykorzystuje właśnie ciało lub głos. Zarówno zachowanie lisa, jak i dźwiękowe komunikaty wydawane przez zwierzę niosą za sobą konkretne informacje, objaśniane w powieści przez narratora: „[Pax] szczeknął, by przywołać Petera” (Pennypacker, 2016, s. 31); „[...] w nocy zawsze skomlał, żeby dostać się do domu” (s. 32). Można zatem stwierdzić, że porozumiewanie się zwierząt (ale też komunikacja międzygatunkowa między lisem i człowiekiem) w powieści odbywa się na poziomie dźwiękowych sygnałów oraz rozpoznanych przez badaczy zwierzęcych gestów. Należy tu jednak zastrzec, że wiedza przyrodników o rzeczywistych znaczeniach rozmaitych lisich zachowań jest wciąż niepełna, a stan badań na temat innych metod komunikacyjnych między zwierzętami okazuje się niesatysfakcjonujący. Problem ten skłania mnie ku refleksji nad inwencją autorską w tworzeniu zwierzęcych postaci; brak kluczowej wiedzy na temat sposobów myślenia oraz porozumiewania się nie-ludzi wydaje się bowiem największą przeszkodą w możliwie wiernym obrazowaniu zwierząt w literaturze.

Pennypacker (2016) objaśnia czytelnikom, że „lisy porozumiewają się za pomocą skomplikowanego systemu dźwięków, ruchów, zapachów i innych środków ekspresji”, których literatura nie jest w stanie uchwycić. Dodaje przy

19 Jednym z pierwszych opracowań, w których został zebrany stan wiedzy o zachowaniach lisów i innych psowatych, jest artykuł Michaela Foxa (1971). 
tym, że powieściowe „dialogi zapisane pismem pochyłym w rozdziałach przedstawiających punkt widzenia Paxa próbują oddać to, co lisy wyrażają swoim rozbudowanym językiem" (s. [4] $)^{20}$ :

To mój teren.

Pax był tak zdumiony, że omal nie spadł z pnia, na którym drzemał. Czuwał cały dzień i nie widział nic większego od pasikonika, a tu nagle zjawiła się lisica o jaskrawym futrze [...].

Ja tu poluję.

Zapragnął uciec do swojego prymitywnego legowiska i mocno przywrzeć do łodyg trojeści, tak jak zrobiłby to w swoim kojcu (s. 42-43).

Cytowany fragment pozwala w przejrzysty sposób zaprezentować obraną przez autorkę strategię. Ponadto ukazuje, jak ciekawy może być efekt niekoherencji, zamieszania narracyjnego, wytworzony przez połączenie formy pierwszoosobowej (w ramach dialogu) z narracją trzecioosobową. $\mathrm{Z}$ jednej strony zamieszanie to pozoruje lisią mowę i płynnie zatapia treści (w założeniu) odzwierzęce w całość narracyjną, z drugiej - u części czytelników może wywołać wrażenia odwrotne, gdyż forma tekstowa przedstawia zwierzęta literackie tak, jak gdyby operowały ludzkim głosem.

Nakładają się tu co najmniej trzy kłopotliwe kwestie (ogólny problem opisu mimetycznego w literaturze, trudny bądź niemożliwy do zastąpienia środek wyrazu literackiego, jakim jest język pisany, a także niedostateczna wiedza ludzi o pozostałych gatunkach), które czynią utwory o zwierzętach nieadekwatnymi wobec rzeczywistości. Pennypacker może tworzyć tylko w ramach języka i dzięki ludzkiej percepcji (także zakotwiczonej w języku), pozostaje jej więc poszukiwanie strategii, kształtujących i pogłębiających efekt prawdopodobieństwa nie-ludzkich postaci. Przykład Paxa dowodzi zatem, że siła literackiego przedstawienia zwierząt nie tkwi jedynie $\mathrm{w}$ opisie zgodnym $\mathrm{z}$ aktualną wiedzą przyrodniczą (choć zmieniający się dynamicznie stan wiedzy o zwierzętach oddziałuje na kształt literatury), lecz także w tekstowym obrazowaniu, które zaskakuje nasze czytelnicze przyzwyczajenia, intryguje odmiennymi technikami prowadzenia narracji, wprowadza do literatury coraz ciekawsze i wiarygodniejsze sylwetki nie-ludzkich wymykające się językowym i literackim stereotypom na ich temat.

20 Warto dodać, że taka konstrukcja tekstu znacząco ułatwia odbiór dziecięcemu czytelnikowi. 


\section{Zakończenie}

Lisy występują w Paxie z całą swoją gatunkową i poznawczą odmiennością doświadczają świata za pomocą zmysłów, kierują się instynktami, nie myślą w sposób abstrakcyjny, a także nie władają ludzkim językiem. Konstrukcja bohaterów zwierzęcych w powieści jest odmienna względem utrwalonych kulturowo przedstawień - lisy są jednostkami sytuującymi się w narracji na równi z człowiekiem, zaś budowa utworu i zastosowane przez Pennypacker posunięcia narracyjne sprzyjają próbom oddania lisiego doświadczenia na gruncie literatury. Choć wierne odbicie rzeczywistości (szczególnie zwierzęcej) w języku nie jest wciąż możliwe, autorka książki dokłada wszelkich starań, by narracja była zgodna z aktualnym stanem wiedzy i obserwacjami przyrodników, co przejawia się w opisach synestetycznych, oddających nieokulocentryczną lisią perspektywę, w specyficznych strategiach narracyjnych oraz w opisach komunikacji niewerbalnej i zachowań zwierząt. Odnarratorskie komentarze służą w znacznej mierze uzupełnianiu wiedzy czytelników na temat życia nie-ludzi, wyjaśniają kwestie, o których zwierzęta nie mogłyby same opowiedzieć. Wyjątkiem na zarysowanym tle są przekazywane w kręgu lisich bohaterów i - według zastrzeżeń autorki - tłumaczone na potrzeby książki złożone zwierzęce komunikaty, pozostające zgrabnym, acz niedoskonałym rozwiązaniem problemu niedostatecznego poznania odmiennych gatunków przez człowieka. Strategia ta sprzyja jednak przystępnemu odbiorowi powieści przez młodych czytelników, co - zważywszy na poruszane w niej trudne tematy: wojny, przemocy, śmierci czy utraty najbliższych - mogło mieć dla autorki przeważające znaczenie.

\section{Bibliografia}

Bakke, M. (2011). Studia nad zwierzętami: od aktywizmu do akademii i z powrotem?. Teksty Drugie, 3, 193-204.

Baratay, É. (2014). Zwierzęcy punkt widzenia. Inna wersja historii (P. Tarasewicz, tłum.). Wydawnictwo w Podwórku. (wyd. oryg. 2012).

Barcz, A. (2013). Zwierzęta mają głos. Teksty Drugie, 1-2, 106-114.

Barcz, A., Dąbrowska, M. (red.). (2014). Zwierzęta, gender i kultura. Perspektywa ekologiczna, etyczna i krytyczna. E-naukowiec.

Braidotti, R. (2013). The Posthuman. Polity Press.

Collodi, C. (1883). Le avventure di Pinocchio. Storia di un burattino. Felice Paggi.

Collodi, C. (1988). Pinokio. Historia drewnianego pajaca (Z. Jachimecka, tłum.). Nasza Księgarnia. (wyd. oryg. 1883). 
Collodi, C. (2011). Pinokio. Historia pajacyka (J. Mikołajewski, tłum.). Media Rodzina. (wyd. oryg. 1883).

Dahl, R. (2017). Fantastyczny Pan Lis (K. Szczepańska-Kowalczuk, tłum.). Znak. (wyd. oryg. 1970).

Dąbrowski, M. (2001). Swój/obcy/inny. Z problemów interferencji i komunikacji międzykulturowej. Świat Literacki.

Derrida, J. (2008). The animal that therefore I am (D. Wills, tłum., M.-L. Mallet, red.). Fordham University Press. (wyd. oryg. 2006).

de Saint-Exupéry, A. (2018). Mały Książę (E. Siwiec, tłum.). Wydawnictwo RM. (wyd. oryg. 1943).

Fox, M. W. (1971). Behaviour of wolves, dogs and related canids. Harper \& Row.

Gajewska, G. (2015). O władzy ludzi nad zwierzętami w kulturze zachodniej - perspektywa posthumanistyczna. Studia Europaea Gnesnensia, 11, 213-234. https:// doi.org/10.14746/seg.2015.11.11.

Gruchlik, H. (2007). Inność a obcość w kontekście filozoficznym. Anthropos?, 8-9. Pobrane 10 listopada $2020 \mathrm{z}$ : http://www.anthropos.us.edu.pl/anthropos5/texty/ gruchlik.htm.

Hamilton, L., Sharpsteen, B. (reż.). (1940). Pinocchio [Pinokio] [film]. Walt Disney Pictures.

Kang, X. (2006). The cult of the fox: Power, gender, and popular religion in late imperial and modern China. Columbia University Press.

Kang, X. (1999). The fox $[h u]$ and the barbarian [hu]: Unraveling representations of the Other in late Tang tales. Journal of Chinese Religions, 27(1), 35-67. https:// doi.org/10.1179/073776999805306777.

Kapuściński, R. (2006). Ten Inny. Znak.

Korpalska, A. (2015). Lis w kulturze Japonii. Tako.

Koizuka, M. (1982). Kitsune monogatari. San'ichi Schobō.

Krasicki, I. (2019). Kruk i lis. Fundacja Nowoczesna Polska. (wyd. oryg. 1779).

Mik, A., Pokora, P., Skowera, M. (2016). Słowo wstępne. W: A. Mik, P. Pokora, M. Skowera (red.), Czytanie menażerii. Zwierzęta w literaturze dziecięcej, młodzieżowej i fantastycznej (s. 9-17). Wydawnictwo SBP.

Mytych-Forajter, B. (2019). Żar popiołów, czyli jak przejść przez lisią norę i przeżyć? Pax Sary Pennypacker. W: A. Czabanowska-Wróbel, K. Zabawa (red.), Żywioły w literaturze dziecięcej. Ziemia (s. 225-234). Wydawnictwo UJ.

Pennypacker, S. (2016). Pax (D. Dziewońska, tłum.). Iuvi.

Rzepnikowska, I. (2016-2018). Lis. W: V. Wróblewska (red.), Słownik polskiej bajki ludowej. Pobrane 10 listopada 2020 z: https://bajka.umk.pl/slownik/lista-hasel/ha$\underline{\text { slo/?id }=100 .}$. 
Skowera, M. (2016). Literackie spotkania istot podporządkowanych. Studium przypadku: Miasteczko Ostatnich Westchnień Grzegorza Gortata. W: A. Mik, P. Pokora, M. Skowera (red.), Czytanie menażerii. Zwierzęta w literaturze dziecięcej, młodzieżowej i fantastycznej (s. 53-74). Wydawnictwo SBP.

von Goethe, J. W. (1973). Reineke Fuchs. Aufbau-Verlag. (wyd. oryg. 1794).

von Goethe, J. W. (1986). Lis Przechera (L. Staff, tłum.). Wydawnictwo Artystyczne i Filmowe. (wyd. oryg. 1794).

Wang, K. (2009). The deviant: Examining the relationship between foxes and humans in Chinese literature. Sino-Platonic Papers, 193, 4-15.

Weil, K. (2014). Zwrot ku zwierzętom. Sprawozdanie (P. Sadzik, tłum.). W: A. Barcz, M. Dąbrowska (red.), Zwierzęta, gender i kultura. Perspektywa ekologiczna, etyczna i krytyczna (s. 15-35). E-naukowiec. (wyd. oryg. 2010).

Wróblewska, V. (red.). (2016-2018). Stownik polskiej bajki ludowej. Pobrane 10 listopada $2020 \mathrm{z:} \mathrm{https://bajka.umk.pl.}$

Zawojski, P. (2017). Posthumanizm, czyli humanizm naszych czasów. Kultura i Historia, 32, 68-76. 